\title{
"You cannot escape where you are from": In Conversation with Rob Doyle
}

\author{
Jonatan González García \\ University of La Rioja, Spain
}

Copyright (c) 2018 by Jonatan González García. This text may be archived and redistributed both in electronic form and in hard copy, provided that the author and journal are properly cited and no fee is charged for access.

\begin{abstract}
Rob Doyle attended the 16th International Conference of the Spanish Association for Irish Studies (AEDEI), held at the University of La Rioja. The following interview took place there on May 26, 2017 and was later expanded through e-mail. Posing a number of questions with a series of illuminating and often provocative responses, it seeks to delve into Doyle's own ideas on Ireland and Irish literature, together with his attitude about life and creative writing, in order to shed some light on what this author looks for and what he wants to prove with his works, an important new voice in Irish writing that is determined to take the tradition in new and significant directions.
\end{abstract}

Key Words. Rob Doyle, Nihilism, Philosophy, Nietzsche, Creative Writing.

Resumen. Rob Doyle asistió al XVI Congreso Internacional de la Asociación Española de Estudios Irlandeses (AEDEI) celebrado en la Universidad de La Rioja. Allí tuvo lugar esta entrevista el 26 de mayo de 2017, que luego se completó por medio de correos electrónicos. La entrevista, en la que Rob Doyle contesta a las preguntas por medio una serie de respuestas esclarecedoras y a menudo provocadoras, pretende indagar en las ideas del propio autor sobre Irlanda y la literatura irlandesa, así como su actitud sobre la vida y la escritura creativa. El objetivo es el de aportar información sobre las inquietudes de este autor y sobre lo que pretende alcanzar con sus obras. Se trata de una destacada voz joven en la literatura irlandesa que sin duda emprenderá el camino de la tradición siguiendo nuevos derroteros.

Palabras clave. Rob Doyle, nihilismo, filosofía, Nietzsche, escritura creativa.

Irish novelist and short story writer Rob Doyle was born and lives in Dublin. He holds a firstclass honours degree in Philosophy, and an MPhil in Psychoanalysis from Trinity College Dublin. Doyle's debut novel, Here Are the Young Men, was published in 2014, first by The Lilliput Press, and then by Bloomsbury. Described by The Irish Independent as "a dark and intoxicating debut describing modern Ireland", by the Sunday Times as "a portrait of a jilted generation", and by John Boyne in The Guardian as "a powerful and provocative novel and easily the most honest account of young Irish people for many years", it follows a group of Irish boys on their first summer of freedom after finishing school in the streets of the Celtic 
Tiger-era Dublin. A summer fuelled by alcohol, drugs, sex and, above all, existential crises. Here are the Young Men was one of Hot Press magazine's "20 Greatest Irish Novels since 1916". Hailed as the Irish Trainspotting, it was further chosen as a book of the year by The Irish Times, The Sunday Times, The Sunday Business Post, and The Independent; and it was shortlisted in the Best Newcomer category for the Bord Gáis Irish Book Awards.

Doyle's second book, This Is the Ritual, was published in January 2016. This collection of stories is clearly marked by the sexual content of some the pieces within, as well as by the unrelenting nihilism of the work as a whole. Aside from his novel and collection of stories, Doyle's fiction, essays, and criticism have appeared in The Guardian, The Observer, The Dublin Review, The Irish Times, The Sunday Times, The Sunday Business Post, Stinging Fly, Gorse, and Dalkey Archive's Best European Fiction 2016, among others. $\mathrm{He}$ is now the editor of the Dalkey Archive's anthology of Irish literature The Other Irish Tradition, due for publication in 2017, and he has further played the lead role in Hit the North (2016), a feature film directed by Daniel Sayer.

Jonatan González García: I would like to begin by asking you about your own conception of what Irish literature is. How do you find it, as a contemporary Irish writer, to labour under the full weight of the long tradition of Irish literature?

Rob Doyle: When I was in my twenties, I mostly read everything except Irish literature. I was one of those maladjusted people who found my own country uninteresting, and was far more powerfully drawn to seeing what the rest of the world and its writers had to say. Nowadays I read a hell of a lot of Irish writing, past and present. I've heard Irish writers of prior generations talk about the oppressiveness of the Irish literary tradition, and James Joyce in particular, but I never felt that. It's related to being part of a generation whose experience is more globalised: I'm as likely to feel daunted by the legacy of, say, a South American writer like Roberto Bolaño, or that of an English writer like Martin Amis, as I am by that of any Irish writer. In general, I don't worry all that much about my relationship to Irish literature. I just get on with writing my own books, which feel to me quite idiosyncratic even in terms of the current landscape of Irish writing.

JGG: Could this view of yours be one of the reasons why, when you first published Here are the Young Men, you actually seem to deviate from the social realist tradition of Irish literature?

RD: I had a strong sense that a book like that - brutal, anarchic, violently irreverent - needed to appear in Ireland, and that when it did, people would respond vividly to it. I was right. I wrote Here Are the Young Men in a state of frustration and exultation - I felt that no-one else was writing about the kind of life I experienced, so I would have to do it myself. If you'd read many of the Irish novels published in the decade or two before Here Are the Young Men, you would think that the stuff I wrote about - drugs, extreme drinking, pornography, subcultural misogyny, video games and so on - didn't exist, and we were all still living in John B Keane country.

JGG: By contrast, what do you make of this topic from the point of view of This is The Ritual - with the first story there constituting a cunning takedown of Ireland's literary heritage, Joyce's Ulysses in particular?

RD: Again, while I was writing This Is the Ritual I wasn't thinking too much about my own relationship to Irish literature, just diving headlong into the themes, landscapes and obsessions 
that compelled me to write. That said, you cannot escape where you are from (believe me I've been trying all my life). The story that you mention, "John Paul Finnegan, Paltry Realist", is pretty much a comically depraved rant against Ireland and the Irish people, and especially the pretentions we have around our literary culture, including the sanctification and sterilisation - of Beckett and Joyce and so on. A lot of people really liked that story and it is good fun, but it's far from my favourite in the collection. It lacks the depth and seriousness of many of the others in This Is the Ritual - even though most of the others are funny serious. Many stories are about sexual themes, psychic disarray, existential horror, drifting outsiders and so on.

JGG: Regardless of your own relationship to Irish literature, Ireland permeates your writings. Here Are the Young Men might, after all, be labelled as a Dublin novel.

RD: I still find almost any other place in the world more alluring and interesting than Ireland, though I'm currently living here. I know how resentful and bad-natured that sounds, but that's the way it is. Having said that, Here Are the Young Men was so very much a Dublin novel - a love/hate letter to Dublin, even. I do love Dublin, though I hate it too. There's so much to hate, and to love. Anyway, Ireland is just a suburb of the US: we ape everything they do, even though they're a declining world power, a collapsing giant of questionable relevance to the global future. People here ape their outlooks, their campus politics, their ideological flavours of the month. Culturally speaking, the Yanks say "jump" and we say "how high?" I don't know what the solution is because I don't yearn for a return to Irish parochialism. Perhaps Russia or China will attain overt global dominance and begin seducing the world through $20^{\text {th }}$ century Yankee-style soft power, so that their culture assumes a dangerous glamour and we follow their lead instead. That would be interesting.

JGG: You are currently seeing to the publication of the Dalkey Archive's Anthology of Irish Literature, a project that you are passionate about. I was wondering if you could give us an overview of this piece of work. What makes it different from other anthologies already on the market?

RD: The Dalkey Archive anthology, which I believe will be titled The Other Irish Tradition, is a celebration of the experimental, subversive, formally inventive strain in Irish literature over the past three centuries. All our greatest writers have been wild experimenters who disregarded or reinvented literary conventions: Joyce, Beckett, Flann O'Brien, Laurence Sterne. Yet this fact tends to get obscured by the primacy afforded in Irish literary culture to a more somber, formally conventional, often rather drab strain of melancholy-realist writing. There has in fact been some great writing in that school, but the Dalkey anthology is an attempt to redress the balance. It will include writers as far back as Laurence Sterne and Jonathan Swift, right up to latter-day rulebook shredders like Mike McCormack, June Caldwell and Kevin Breathnach. There are also some juicy surprises and hidden treasures in there. In short, it's going to be a great book, so everyone should buy a copy, and additional copies for their family members, lovers and pets.

JGG: I feel that there is an issue that is bound to come up at some point, so perhaps it is better to get it out of the way this very moment: Frederick Nietzsche. Do you recall the first time that you came across his work? Did it have an immediate influence upon you?

RD: I can't remember the precise moment but I must have become aware of Nietzsche in my late teens. Then I went to study philosophy and while a lot of the stuff I encountered there left 
me cold, Nietzsche became a powerful, profound, abiding fascination. He still is. I grew up in a Catholic family, and so discovering this genius thinker who hurled my entire worldview on its head, casting my most cherished assumptions into disrepute, was an astonishing, seriously disturbing experience. There is so much richness and wonderment in Nietzsche's work. The fact that he existed at all is one of the miracles of human history. At the same time, he is profoundly dangerous. It's like Niels Bohr reputedly said of quantum physics: if it doesn't shock you, you haven't understood it.

JGG: The German philosopher markedly hovers over both Here are the Young Men and This is the Ritual, but in strikingly different ways. What do you make of the weight of Nietzschean ideas in each of your two books?

RD: Here Are the Young Men is peppered with unattributed and defaced Nietzsche quotations. The ideas are there in the background, a sort of climate, only because I have been passionately engaged with Nietzsche's thinking for my whole adult life, so it would not be possible for me to write fictions or anything else without his influence making itself felt. It's not that the novel or stories are attempts to give fictional form to his ideas - that would be uninteresting but that I live and the characters live in a world over which the specter of Nietzsche hovers, cackling demonically.

JGG: Very many thanks for that honest answer. Indeed, while perhaps we might go as far as to say that Nietzschean ideas are a structuring force in your debut novel, in your collection of stories it appears as if Nietzsche is lingering there - and this is specially the case in your story "On Nietzsche". Focusing, however, on your writing process: are you the kind of writer whose texts tend to experiment major changes between their original inception and their final published state?

RD: I revise relentlessly. After I write a first draft, that's when the real work - and often, the real pleasure - begins. A first draft is usually a crude, dismaying thing: it's like a big block of marble in which you can just about discern the outline of the form you are seeking to unlock. You need to chisel and polish and brush away all the dust before the perfect object is revealed, the true form. When it is revealed, it's worth all the effort, all the toil and anguish of writing. I'm a perfectionist: I don't want to present sentences to the world that are not excellent. I'm with the fascistic music teacher in the film Whiplash: there are no two words more harmful in the English language than "Good job".

JGG: I have noticed that you usually carry a small notebook with you. Does it serve a prominent purpose in your creative process?

RD: I carry a notebook everywhere, but that doesn't mean I'm always writing in it. I have a suspicion of those writers who insist on writing a certain amount of words every single day. I want to ask them, "What, even when you have nothing to say?" I think it's good to maintain a healthy skepticism towards writing and literature, to assume that more than enough books already exist in the world - too many, even - and that if you really must write another, then make it count. But yes, I often jot down notes, sometimes several pages of them, then I go home and type it on my laptop. You might be anywhere when inspiration hits: walking around the tenth arrondissement Paris, say, on one of those dreamlike, exalted hungover afternoons. That's where the notebook comes in. 
JGG: Let's go back for a second to the main themes that permeate your oeuvre: sex, drugs, travel, as well as philosophy and literature itself. An idea that you advance at various points in both Here are the Young Men and This is the Ritual is that, for a writer, experiences are the best teachers. That is, you have to live in order to be able to write, because no one can teach you, in the formal sense, to be a writer. Even if, by all means, reading is an experience that you cannot leave behind.

RD: I write of what I'm passionate about and what captures my imagination, and that includes sex, drugs, travel, philosophy, literature itself, love, romance, music, the artistic life. In This Is the Ritual I write about drifters, people who live or wander in foreign countries, struggling to find a way to live without going under. Or people who are smashed by forces beyond their comprehension, which rise up from the depths. When I was twenty-three and finished college I left Ireland to wander around the world, and I didn't really come back until I was thirty. Then I kept going away again. Some writers prefer to stay in the same place and lock the door and make stuff up every day, and that can work too, but for me writing has been inseparable from this unignorable desire to see the world, which often has led to me being ripped to shreds by horrible personal problems, heartbreak, loneliness, confusion, and so on. But that's what I've been compelled to do and that's what has fed my writing.

JGG: Bearing this in mind, what are your views on the courses and degrees on Creative Writing that are on offer nowadays in many universities both in Europe and in the United States?

RD: I hate them. No, that's not quite true, but I am suspicious of them. It's undeniable that they produce a fair number of good writers whose work I admire. But I've always liked the perhaps somewhat archaic, certainly romantic notion of the writer as a traumatised outsider, who writes not according to the templates and formulae offered by schools of Creative Writing, but from an unbearable compulsion that arises from a wounding, overwhelmed relationship to existence. Having said that, I sometimes teach Creative Writing myself, and I like to think my students get a lot from my classes. I focus on superb writing by past and present masters: we read their work, try to understand what they were doing, and then use that as inspiration to write work of our own. I have little patience for anyone who thinks you can be an interesting writer without avidly reading, serving an apprenticeship at the feet of the masters. I am fond of quoting Bolaño: "Reading has always been more important than writing".

JGG: I mentioned earlier how travel is one of the main ideas that permeate your writings, both as a theme and as a source of influence. With reference to Spain, I was wondering if you could tell us something about the weight that your visits to this country have had in your portrayal of the Spanish motifs and references that we sometimes find in your writings. I am particularly thinking about your careful and minute descriptions of the streets, shops and people of Barcelona in your eponymous short story from This is the Ritual; as well as to other seemingly minor references, such as Matthew's allusion to the "mad fucker" Spaniard that smokes like a chimney in the opening section of Here are the Young Men.

RD: I wrote the story "Barcelona" before I had ever been to the city. It was one of those instances where longing and desire found expression in writing: I wrote about a place as a substitute for going there. Place in general is a major aspect of my writing, the fiction and the non-fiction, but more often I write about places where I have been or lived, so that I can dwell 
in those places in my imagination. Spain appeals to me very much and for the past couple of years I've fantasised about living there. It may still happen, but it hasn't happened yet. In the book I'm working on now, two of the chapters involve trips to Spain. One of them is about the town of Blanes on the Costa Brava, where the Chilean writer Roberto Bolaño lived much of his life. The other concerns a music festival in Barcelona. This time I actually visited the locations before writing about them, rather than making it all up.

JGG: Apart from being a writer, you have played the lead role in Hit the North (2016), a feature film directed by Daniel Sayer. Was this your first acting experience? How did you find having to impersonate a character instead of creating one?

RD: It was tremendous fun! I loved acting in Hit the North, and it turned out to be a beautiful film, although very few people have seen it as of yet. It's shot mostly in black and white, with lots of long, moody scenes - my character walking across grim, windswept landscapes and so on. A lot of drinking and ennui and rambling improvised dialogues. We used an image from the film as the cover on the Lilliput Press limited edition of This Is the Ritual - it's my character, "the Hitcher", standing on a bridge in the sea on a bleak and remote part of the Scottish coast. Both ends of the bridge are submerged in the tide, which is rising. An extraordinary image.

JGG: In this respect, does getting under the skin of a character that appears to suffer from an existential crisis, a character that someone else has conceived, does it make you look in a different way at the characters that people your own writings and which are also involved in existential crises?

RD: I've always written about people who are psychically and existentially on the edge because, quite simply, I have known so many people like that throughout my life, and I have often been in a perilous condition myself. My characters tend to be isolated, lonely, neurotic, sexually deviant, violent, tormented, disturbed, or outright mad. They are also often tender, vulnerable, hurt, and long for affection and meaning and solace. Life is not easy, it's hard and brutal and full of raw anguish, a terrifying adventure. I'm hanging on for dear life, and I assume the rest of you are too, and so I write for people who are desperate and anguished and full of longing.

JGG: Having you here, I think it would be a shame to miss the chance of asking what you are working on at the moment. Are there any new projects in the horizon aside from the Dalkey Archive anthology?

RD: Yes, I am also working on my next book, which is quite different to both my previous ones. It's a novelish memoir or a memoirish novel. It's not entirely unfictional, but mostly it's made up of true personal experiences. Thematically it isn't all that distant from what I've written before: sex, neurosis, metaphysics, psychedelic drugs, writers, the threat of madness and so on. It's funny too, like my other books. Every chapter is a standalone account of a trip or encounter I had, in a number of countries, but the whole thing is structured as an overarching narrative. In short, it's hard to describe because it's not your basic meat-and-twoveg novel, but more like a hybrid of fiction, essay, travel writing, humour, pornography, and renegade metaphysics. I'm also working on another book combining travel writing, photography and confession in collaboration with another writer. 
JGG: I would like to finish this interview by thanking you for your time and patience, Rob. It was a real pleasure that you accepted our invitation to read and discuss your work in La Rioja in May 2017 during the XVI International Conference of the Spanish Association for Irish Studies (AEDEI), and I am grateful for your being so kind and generous with this interview afterwards.

\section{Works Cited}

Boyne, John. "John Boyne's Top 10 Child Narrators". The Guardian. 24 July 2014. 1 July 2017. https://www.theguardian.com/childrens-books-site/2014/jul/24/top-ten-childnarrators-john-boyne

Coffey, Edel. "Hedonistic but Joyless Coming of Age in Dublin". The Irish Independent. 9 June 2014. 1 July 2017. http://www.independent.ie/entertainment/books/bookreviews/books-hedonistic-but-joyless-coming-of-age-in-dublin-30334433.html

Doyle, Rob. Here are the Young Men. London: Bloomsbury, 2014.

—. This is the Ritual. London: Bloomsbury, 2016.

- ed. The Other Irish Tradition. Dublin: Dalkey Archive Press, 2017.

Sayer, Daniel. Hit the North. London: Rabblewise Films, 2016.

Shortall, Eithne. "Elegantly Wasted". The Sunday Times. 19 June 2014. 1 July 2017. https://www.thetimes.co.uk/article/elegantly-wasted-d8njf76mtbm

Received: 25 August 2017

Revised version accepted: 09 October 2017

Jonatan González García is a PhD candidate at the University of La Rioja researching Anglo-Spanish literary and cultural relations and the reception of British Romantic poetry in continental Europe. He is writing his thesis on the afterlife of William Wordsworth in Spain, and is particularly interested in the place Wordsworthian texts have occupied in the political and cultural landscape of the Iberian nation for the past two hundred years. He is one of the founding members of the Centre for Irish Studies BANNA / BOND, a regional EFACIS centre set up between the Universities of Burgos, Deusto, La Rioja and Zaragoza. He has written articles on Robert Southey, William Wordsworth, Samuel Taylor Coleridge, and the reception of the Romantics in twentieth-century Spain for several Spanish and English journals, including Odisea: Journal of English Studies, EREBEA: Revista de Humanidades y Ciencias Sociales, The Coleridge Bulletin or Romanticism and Victorianism on the Net. Together with Cristina Flores, he is currently working on a scholarly edition of Robert Southey's 1797 travelogue Letters Written During a Short Residence in Spain and Portugal. With Some Account of Spanish and Portugueze Poetry, to be published by Routledge.

jonatan.gonzalezg@unirioja.es 